\title{
MICHAŁ ZEMBRZUSKI
}

\section{„O MIŁOŚCI! CÓŻ MOGĘ O TOBIE POWIEDZIEĆ?" HUGONA ZE ŚW. WIKTORA POCHWAŁA MIŁOŚCI}

\section{WPROWADZENIE}

Św. Tomasz z Akwinu w jednej z kwestii z Komentarza do Sentencji Piotra Lombarda ${ }^{1}$, która dotyczyła relacji zachodzących między poznaniem a miłością, zanotował argument pochodzący z Komentarzy do Hierarchii anielskiej Pseudo-Dionizego, które napisał Hugon ze św. Wiktora². Wedle niego miłość miała być wyższa niż jakakolwiek wiedza i rozumienie, ponieważ „więcej” się kocha niż rozumie, a miłość dociera do tego, wobec czego poznanie jest w pewien sposób „,na zewnątrz”. Gdyby takie sformułowanie przyjął za swoje, to osławione intelektualistyczne podejście zostałoby co najmniej zawieszone. Tomasz chylił czoło przed tym wybitnym zakonnikiem, co

To mas z z A k w in u, Super Sent., III, d. 27, q. 1, a. 4, arg. 10 (wyd. M.F. Moos, Parisiis 1933, s. 867).

2 Zob. Hugon z e św. W i k t or a, Commentaria in Hierarchiam coelestem s. Dionysii Areopagitae (PL 175, 1038D). „Tunc enim nihil duritiae obsistet, ut ad intima charitas perveniat, et acutum habeat omnia penetrare dilectio; hoc nobis dicendum erat, pro acuto dilectionis, et liquido ut inielligas vim amoris et dilectionis quanta est. Si tamen hoc intelligi potest, quoniam dilectio supereminet scientiae, et major est intelligenlia. Plus enim diligitur, quam intelligitur, et intrat dilectio, et appropinquat, ubi scientia foris est". 
wykazał w wielu miejscach swoich dzieł, a rozstrzygnięcie Hugona na temat miłości również uznał, co najwyżej dopowiadając, że musi to dotyczyć wyjątkowego przedmiotu, jakim jest Bóg ${ }^{3}$. Potwierdził więc, że dzięki miłości kochający zostaje udoskonalony przez przedmiot kochany w o wiele większym stopniu niż to czyni poznanie, w człowieku poznającym.

To twierdzenie Akwinaty i przywołana teza Hugona - niezwykle zresztą frapująca - stały się powodem poszukiwań rozumienia miłości w tekstach tego XII-wiecznego autora. Sam Hugon słowami pełnymi pokory, zdając sobie sprawę, że temat był podejmowany przez wielu autorów, ale i niewyczerpany ${ }^{4}$, zapowiada poszukiwanie wyjaśnienia tematu miłości na samym początku De laude caritatis: „Tak wielu jest już znanych nam wielbicieli miłości, że gdybym ja miał od początku dla jej uwielbienia cokolwiek powiedzieć, to bliższe by to było arogancji niż pobożności"5.

Hugona nazywano w średniowieczu „nowym Augustynem”. Był niezwykle wpływowym teologiem i egzegetą, a także filozofem, choć z pewnością nie w nowożytnym czy współczesnym znaczeniu. Bez wątpienia dostrzegał różnicę między dyscyplinami teologicznymi i filozoficznymi, gdyż dostrzegał odrębną strukturę aktu rozumu, który może nie potrzebować pomocy wiary, by wyjaśnić swój przedmiot (np. temat przedmiot matematyki, fizyki, logiki czy mechaniki $)^{6}$. Dostrzegał jednocześnie, że to przedmiot wyznacza odpowiednią dziedzinę, czemu dał wyraz w swoim powszechnie

3 Zob. H. F e is s, On love. A selection of works of Hugh, Adam, Achard, Richard, Godfrey of St. Victor, Brepols, Turnhout 2012, s. 105-109.

4 Spośród XII-wiecznych gigantów piszących na temat miłości można wyliczyć: Bernarda z Clairvaux, Wilhelma z Saint-Thierry, Aelreda z Rievaulx, Guigo Drugiego.

5 Hugon ze św. Wiktora, De laude charitatis (PL 176, 971B). „Tam multos jam laudatores charitas habuisse cognoscitur, ut si quid ego in laudem ejus dicere coepero, praesumptio fortassis magis quam devotio videatur".

6 Zob. S. J a n e c z e k, Hugon ze św. Wiktora. Myśl filozoficzna, „Powszechna Encyklopedia Filozofii”, t. 4, Lublin 2003, s. 622. 
znanym Didascaliconie ${ }^{7}$. Hugon jednak nie skupiał uwagi i nie marnował czasu na samodzielne badania rozumowe. W ogromnej spuściźnie Hugona, poza dziełami poświęconymi dydaktyce i pedagogice, odnaleźć można systematyczne dzieła teologiczne, egzegetyczne, a także mistyczne, w których pojawia się temat miłości ${ }^{8}$. Zasadniczy sens jego teologicznych wypowiedzi związany był z ,przywracaniem formy (re-formatio)", którą człowiek utracił w wyniku grzechu9. Ten temat, i to również w kontekście tematu miłości, został przez niego podjęty także w kilku pomniejszych, okolicznościowych pismach (są to głównie kazania i listy): „O chwale miłości (De laude charitatis)”, „O substancji miłości (De substantia dilectionis)”, „O tym, że miłość Boga jest życiem serca (Quod amor Dei sit vita cordis)”, „O miłości Oblubieńca do oblubienicy (De amore sponsi ad sponsam)". Oczywiście temat miłości był niezwykle popularny także wśród innych, najważniejszych przedstawicieli szkoły Wiktorynów ${ }^{10}$. Temat ten

7 Hugon ze św. Wiktor a, Eruditionis didascalicae II, 2 (PL 176, 752B).

8 Nie przypadkiem w Didascaliconie pojawiają się znamienne słowa, którymi Hugon zachęca do studiowania każdej dziedziny wiedzy i propaguje swoisty maksymalizm poznawczy: „Ucz się wszystkiego, a zobaczysz potem, że nic nie jest zbędne”. Zob. Hugon ze św. Wiktora, Eruditionis didascalicae VI, 3 (PL 176, 801A). „Omnia disce, videbis postea nihil esse superfluum”. Nie oznacza to dla Hugona zdobywania wiedzy dla niej samej. Jak pisze R. Tichy, „wiedzę należy zdobywać tylko po to, by ją przekroczyć, przemienić w kontemplację mistyczną. Stąd nauka, która polega na zdobywaniu wiadomości o świecie (cogitatio), powinna być przez człowieka zawsze spożytkowana w procesie wewnętrznego doskonalenia (meditatio), a ostatecznie prowadzić do wejścia na płaszczyznę kontemplacji (contemplatio), gdzie poznanie i miłość, łącząc się w jeden wspólny akt, dotykają tego, co boskie". R. T i chy, Hugon ze św. Wiktora, w: M. Fr a n k ow s k a-Te r le ck a (red.), Wszystko to ze zdziwienia. Antologia tekstów filozoficznych z XII wieku, Warszawa 2006, s. 277.

9 B. T. C o o $1 \mathrm{~m}$ a n n, The theology of Hugh of St. Victor. An interpretation, Cambridge University Press, New York 2010, s. 12-29.

10 Bardzo niezwykłą duchową charakterystykę opactwa daje P. Rorem. Pisze on o tym, że kanonicy regularni, żyjący w tym miejscu wypełniali ogromną lukę jaka zaczynała istnieć między mnichami a nauczycielami w średniowiecznym Paryżu. O ile pierwsi poświęcali się uczeniu i nauczaniu, drudzy modlitwie i opłakiwaniu świata, kanonicy ustawiali się pośrodku, ale odrzucali możliwość pozostania 
poza Hugonem poruszali: Adam ze św. Wiktora, Ryszard (autor traktatu -O czterech stopniach żarliwej miłości - De quatuor gradibus violentae caritatis), Achard, a także Godfryd. Temat ten, być może był o wiele lepiej opracowany przez innych autorów (bardziej systematycznie), takich jak Bernard z Clairvaux ${ }^{11}$ czy Aelreda z Rievaulx ${ }^{12}$. Jednak Hugon wydaje się być jednym tych, których pochwała miłości domaga się odczytania i zaprezentowania.

\section{MILOŚĆ W TRAKTATACH MISTYCZNYCH HUGONA}

Problematykę miłości podejmuje Hugon w „trylogii” mistycznej, w której metafora arki Noego stała się podstawą opisania działania Boga w duszy człowieka. Do tej grupy dzieł należą: De archa Noe morali (De archa Noe); De archa Noe mystica (Libellus de formatione arche); Soliloquium de archa animae. Dla Hugona metafora łodzi jest znakomitą okazją do zaprezentowania tej tematyki. Należy jedynie zaznaczyć, że miłość staje się ważna ze względu na sposób opisywania samych relacji między Bogiem i duszą, w której budowana jest arka $^{13}$. Schemat we wszystkich dziełach mistycznych generalnie jest taki sam: 1) ludzkie serce/dusza jest zwrócona do Boga; 2) Bóg znajduje mieszkanie w człowieku dzięki wiedzy i miłości; 3) wiedza odpowiada za konstrukcję arki (której odpowiada cnota teologiczna wiary); 4) miłość daje jej piękno i ozdobę (ornamentum); 5) Bóg mieszka w arce duszy jako Jego świątyni; 6) arka broni przed potopem i sprowadza Boga do jej wnętrza, który ją zamieszkuje jako sternik lub kapitan. Najlepiej Hugon wyraża to w pierwszym z dzieł,

dylemacie nie do rozwiązania. Zob. P. R o r e m, Hugh of Saint Victor, Oxford University Press, New York 2009, s. 6.

11 Zob. R. T i c h y, Mistyczna historia człowieka wedtug Bernarda z Clairvaux, Kraków 2011, s. 232-255.

12 Zob. M. C z u b a k, Jednostka $i$ wspólnota $w$ ujęciu Aelreda z Rievaulx, Warszawa 2010, s. 59-116.

13 A. S qui r e, Introduction, w: Hugh of Saint Victor. A Selected Spiritual Writings, Harper \& Row, New York-Evanston 1962, s. 24-29. 
w De archa Noe morali: „Bóg dwojako mieszka w sercu człowieka, a mianowicie przez poznanie i miłość. Te dwa działania znajdują się jednak w jednym miejscu, gdyż każdy kto poznaje Boga, robi to z miłością, i nikt nie może kochać Boga nie poznając Go. W tym jednak wydają się różnić, że wiedza ustanawia budowlę wiary przez poznawanie jej, podczas gdy miłość jakby ozdabiający kolor upiększa jej strukturę przez cnoty. Tak więc każda z nich wydaje się być konieczna dla drugiej, gdyż budowla nie uzyska sławy, jeśli jej w ogóle nie będzie, oraz nie będzie się podobać, jeśli nie będzie rozsławiona"14.

\section{AUGUSTYŃSKIE ŹRÓDŁA KONCEPCJ I MIŁOŚCI}

Koncepcja miłości, jaką posiadał Hugon, ma wyraźnie proweniencję Augustyńską i to zarówno co do treści, jak i co do pewnego zasadniczego założenia. Augustyńska koncepcja miłości charakteryzuje się przede wszystkim tym, że jej funkcjonowanie związane jest z fundamentalnym brakiem ścisłych terminologicznych odróżnień między caritas, dilectio, amor, filia ${ }^{15}$. Wynikało to z braku ścisłości i braku dystynkcji w terminologii biblijnej, na której opierał się zasadniczo biskup Hippony. I nie chodzi tu wcale o wieloznaczne użycie tych terminów, ale o to, że słowem amor albo też dilectio czy caritas, mogła być opisywana relacja między Bogiem i człowiekiem oraz człowiekiem i Bogiem ${ }^{16}$. Ten brak ścisłości terminologicznej można

14 Hugon ze św. Wiktor a, De archa Noe morali I, 2 (PL 176 621D). „Duobus modis Deus cor humanum inhabitat, per cognitionem videlicet et amorem, una tamen mansio est, quia et omnis qui novit cum diligit, et nemo diligere potest qui non novit. In hoc tamen differe videtur, quod scientia per cognitionem fidei fabricam erigit, dilectio autem per virtutem quasi colore superducto aedificium pingit. Sic autem utrum libet necessarium porspicitur, quia nec splendere potest si non fuerit, nec placere si non splenduerit".

15 Zob. A. A nd r z e j u k, Metafizyka obecności. Wstęp do teorii relacji osobowych, Warszawa 2012, s. 183-188.

${ }_{16}$ Augustyn w O Państwie Bożym wręcz zwraca uwagę, że w ramach ,pism naszej religii” nie należy wprowadzać w tym temacie szczegółowych dystynkcji: 
dostrzec u samego Hugona. Odróżnianie poziomów oraz rodzajów miłości właściwej dla różnych bytów, jest dziełem innych myślicieli XII-wiecznych, a na pewno już scholastyków z XIII wieku.

Zasadnicze określenia miłości można odnaleźć w poszczególnych najważniejszych dziełach św. Augustyna. W Wyznaniach miłość jest określona jako ruch (pondus) oraz niezaspokojone pożądanie serca $^{17}$. W traktacie $O$ Trójcy świętej działanie miłości sprowadza się do jednoczenia podmiotu z przedmiotem, kochającego i tego, co on kocha ${ }^{18}$. W Państwie Bożym Augustyn określił miłością każdą cnotę (dotyczy to czterech cnót kardynalnych), która staje się formą miłości - każdy, kto posiada uporządkowaną miłość, będzie posiadał cnoty $^{19}$. W ten sposób, w tradycji chrześcijańskiej, cnota stała się wyrazem porządku miłości w działaniach człowieka. W Contra Faustum miłość zostaje określona wedle zachowań człowieka, w zależności od tego, jakim jest człowiekiem - czy jest zły czy jest dobry, taką posiada miłość (talis est quisque, qualis eius dilectio) ${ }^{20}$. Miłość o charakterze społecznym ze względu na dwa różne cele wyznaczające różne społeczności stała się przedmiotem rozważań traktatu Państwo $B o \dot{z} e^{21}$. Kluczowe jednak i niemalże rozpoznawcze jest pojawiające

\footnotetext{
„Dlatego tu o tym wspomniałem, że niektórzy myślą, iż co innego jest ukochanie (dilectio), czyli szacunek (caritas), a co innego miłość (amor). Powiadają mianowicie, że ukochanie odnosi się do czegoś dobrego, a miłość - do złego. Tymczasem wiadomo to powszechnie, że też i pisarze świeccy tej różnicy nie robią. Toż samo i filozofowie żadnego powodu takiej różnicy nie przytaczają i jej nie zachowują (...) Ale nade wszystko nasze księgi święte, których powagę cenimy wyżej nad wszelkie inne księgi, bynajmniej nie mówią, iżby co innego miłość znaczyć miała, a co innego ukochanie, czyli szacunek, czegośmy już dowodzili”. A u g u s t y n, Państwo Boże XIV, 7, (tłum.) T. Kubicki, Kęty 2015, s. 515-516.

${ }_{17}$ A u g u s t y n, Wyznania I, 1, (tłum.) Z. Kubiak, Kraków 2008, s. 27.

18 A u g u s t y n, O Trójcy świętej VIII, 10, 14, (tłum.) M. Stokowska, PoznańWarszawa-Lublin 1962, s. 276.

19 A u gu s t y n, Państwo Boże XV, 22, dz. cyt. 583.

20 A u g u s t y n, Contra Faustum V, 11 (PL 42, 228). „(...) quia ex amore suo quisque vivit, vel bene vel male. Vos autem si spiritalis atque intellegibilis boni caritate, ac non corporalium phantasmatum cupiditate arderetis".

${ }^{21}$ A u gu s t y n, Państwo Boże XIV, 28, dz. cyt., s. 546-547.
} 
się w $O$ nauce chrześcijańskiej odróżnienie dwóch rodzajów dóbr i w związku z tym dwóch rodzajów miłości - uti i frui ${ }^{22}$.

Augustyńska koncepcja miłości w sposób zdecydowany zaważyła na myśli Hugona. I choć w większości swoich wypowiedzi i miłości podąża on za Augustynem, to można jednak dostrzec pewne odstępstwa i próbę zrewidowania zapatrywań biskupa Hippony. Dotyczy to szczególnie rozumienie przedmiotu miłości. Hugon zasadniczo nie używa podziału miłości na uti i frui. Ta Augustyńska dychotomia jest zbyt „drastyczna”, gdyż wprowadza podział dóbr i porządek miłości skierowanej wyłącznie na Boga. Wedle Augustyna tylko Bóg jest właściwym przedmiotem miłości i radości jako kres i cel wszelkich działań. Dostępnego nam świata powinniśmy używać - korzystać $\mathrm{z}$ niego - ale nie powinien być przedmiotem radości. $Z$ takiej miłości Boga wynikałaby pogarda i ucieczka ze świata, do której Wiktoryni nigdy nie zachęcali, nawet jako kanonicy reguły św. Augustyna. Ich opactwo mieściło się przy granicach miasta i nie separowało się od niego - czym zresztą zyskali pogardę cystersów, a szczególnie Bernarda z Clairvaux. Hugon w swoich dziełach zwraca uwagę na powstrzymywanie się od pożądliwości ciała ${ }^{23}$, jednak koncentruje

22 A u g u s t y n, O nauce chrześcijańskiej I, IV, 4, (tłum.) J. Sulowski, Warszawa 1979, s. 22

23 W De substantia dilectionis pisze o tym, że źródłem pożądania (cupiditas) jest również miłość (dilectio). Pożądliwość jest pragnieniem i wyrazem kierowania się ku przedmiotom zewnętrznym. Pragnienie przedmiotów wewnętrznych zyskuje właściwą nazwę miłości (caritas). Pożądanie staje się korzeniem wszelkiego zła, zaś miłość wyraża dobro. Ważna jest jednak uwaga, że to wyjątkowe źródło miłości, z którego wychodzą dwa strumienie, swoje miejsce ma w człowieku. Zob. De substantia dilectionis (PL 176, 15A). „Quotidianum de dilectione sermonem serimus, ne forte non advertentibus nobis scintillet in cordibus nostris est exardescat ignis flammam faciens, aut totum consumens aut purgans totum. Ex eo namque totum est quod bonum est, et totum quod malum est ex eo est. Unus fons dilectionis intus saliens duos rivos effundit. Alter est amor mundi, cupiditas; alter est amor Dei, charitas. Medium quippe est cor hominis unde fons amoris erumpit, et cum per appetitum ad exteriora ducitur, cupiditas dicetur; cum vero desiderium suum ad interiora dirigit, charitas nominatur. Ergo duo sunt rivi qui de fonte dilectionis emanent, cupiditas et charitas. Et omnium malorum radix cupiditas, et omnium 
się o wiele bardziej na temacie kierowania i rozwoju (na dynamice) miłości względem prawdziwej oraz wiecznej radości. Dodatkowo Hugon podkreśla wartość przyjemności płynącej z doświadczania świata (w postaci choćby przyjemności z oglądania świata), gdyż jest ona zapowiedzią radości wiecznej ${ }^{24}$. W ten sposób przyjemność zmysłowa wpisywała się w mistyczną drogę człowieka do Boga, przez co jego ujęcie różniło się od rozumienia Bernarda z Clairvaux.

Hugon w De substantia dilectionis wypowiada następujące słowa, definiując samą miłość: „Wydaje się więc, że miłość (amor) jest pragnieniem (dilectio) serca do czegoś i ze względu na coś - pożądaniem w pragnieniu i rozkoszowaniem się w radości - przez pożądanie miłość biegnie a odpoczywa przez radość" 25 . Uti i frui przestają być zasadniczym znakiem rozpoznawczym, a główną rolę odgrywa bieg i spoczynek (cursus i requies).

W kolejnych fragmentach De substantia dilectionis odnaleźć można powiązanie biegu i odpoczynku z trzema przedmiotami miłości: „Trzy są rzeczy, które mogą być dobrze, bądź źle kochane: Bóg, bliźni i świat. Bóg jest ponad nami, bliscy są na równi, świat jest pod nami"26. Hugon sugeruje uporządkowanie miłości ze względu na te trzy grupy przedmiotów, jednocześnie zaznaczając rację tego porządku (racja jest oczywiście moralna): ,Jeśli biegniesz, biegniesz

bonorum radix charitas. Ex eo igitur totum est quod bonum est, et totum quod malum, ex eo est. Quidquid ergo illud est, magnum est quod in nobis est, et ex eo totum est, quod inest nobis, ex hoc autem amor est".

${ }_{24}$ Zob. W. B a j o r, «Zbawcze piękno» w teorii estetycznej Wiktorynów, „Roczniki Kulturoznawcze", 3(2012), s. 69.

25 De substantia dilectionis (PL 176, 16A). „Amor est dilectio cordis alicujus ad aliquid propter aliquid: desiderium in appetendo et in perfruendo gaudium: per desiderium cuerens, requiescens per gaudium". Nieco niżej powtarza to określenie miłości, ale akcent kładzie już nie na pragnienie, ale na to, że miłość jest relacją: „Miłość jest bowiem zwróceniem się serca czegoś jednego do czegoś drugiego, ze względu na coś”. De substantia dilectionis (PL 176, 16D). „Est enim amor dilectio cordis alicujus ad aliquid propter aliquid".

26 De substantia dilectionis (PL 176, 17A), „Tria quaedam sunt quae amari bene aut male possunt, id est Deus, proximus, et mundus. Deus supra nos est; proximus juxta nos; mundus subtus nos est". 
dobrze, jeśli odpoczywasz, odpoczywasz właściwie. Pragnienie biegnie - radość odpoczywa”27. Wcześniejsza różnica między biegiem i odpoczynkiem zostaje wzmocniona określeniami pragnienia i radości. Radość wedle Hugona posiada jedną, jedyną formę i zawsze pozostaje niezmieniona przez jakiekolwiek następstwo, z kolei pragnieniu towarzyszy zmienność i z tego powodu nie trzyma się jednego przedmiotu, ale realizuje się w różnych formach. Hugon dalej dopowiada uwagi na temat biegu: „wszelki bieg (podążanie) jest skądś (de), w czymś (in), oraz jest zwrócony ku (ad quod) czemuś" 28 . Ze względu na te trzy „wyznaczniki” - „wektory”, Hugon określa miłość względem Boga, bliźnich i świata, jednocześnie zaznaczając, że skierowanie ku Bogu (cursus ad Deum) posiada wszystkie trzy charakterystyczne elementy, miłość bliźnich tylko dwa, zaś skierowanie ku światu wyłącznie jeden.

Hugon w następujący sposób charakteryzuje miłość człowieka do Boga: „W pragnieniu występuje uporządkowana miłość, gdy może biec od Boga, z Bogiem i ku Bogu. Miłość biegnie od Boga, gdy od Niego otrzymuje to, dzięki czemu może do Niego dojść. Miłość biegnie z Bogiem, gdy w niczym nie sprzeciwia się Jego woli. Miłość ku Bogu zmierza, kiedy w nim odpoczywa" 29 .

Wskazując na dwa „wektory” miłości względem najbliższych, podkreśla, że „pragnienie może biec od nich i z nimi, lecz nie może być [skierowane] w nich (de ipso, cum ipso, non in ipsum). Pragnienie biegnie od, jak gdyby ze względu na nich, gdy raduje się z powodu ich zdrowia i ich powodzenia. Miłość biegnie razem z nimi (cum proximo), gdy człowiek pragnie mieć ich na swojej drodze zarówno jako towarzyszy i jako wspólników w dotarciu do celu. Nie może

27 Tamże. „Si currit, bene currat; si requiescit, bene requiescat. Desiderium currit, gaudium requiescit".

28 Tamże (PL 176, 17B). „Omnis namque cursus aut de illo est, aut cum illo, aut in illo ad quod est".

${ }_{29}$ Tamże. „Amor namque per desiderium, et de Deo, et cum Deo, et in Deum ordinate currere potest. De Deo currit quando de ipso accipit unde et eum diligit. Cum Deo currit, quando ejus voluntati in nullo contradicit. In Deum currit, quando in ipso requiescere appetit". 
jednak biec ku bliźnim, gdyż nie może utrzymać się w ludziach nadzieja i zaufanie" 30 .

W przypadku miłości świata, tylko jeden wyznacznik zostaje do niej przyłączony: ,jest jedna rzecz, która przysługuje miłości do świata - bieg z niego (de ipso), a nie razem z nim, czy ku niemu. Pragnienie biegnie ze świata, gdy oglądając z zewnątrz dzieła Boże (dusza) zwraca się do wnętrza przez podziw i chwałę, by być bardziej gorliwą względem Niego. Pragnienie mogłoby biec ze światem, gdyby z racji zmienności rzeczy czasowych - czy to przez pokonanie niepowodzeń czy to przez podniesienie stanu pomyślności - mogło przeformułowywać się ze względu na ten czas. Pragnienie mogłoby biec ku światu, gdyby mogło się zaspokoić na zawsze w jego przyjemnościach"31. Nie można zatem kochać świata (w sensie zwracania się ku niemu), gdyż nie zostaną zaspokojone nasze pragnienia tym co zmienne, pragnienie nie może biec razem ze światem, gdyż uniemożliwiają to zmiany temporalne.

Te uwagi Hugona przedstawiają miłość jako coś wyjściowego (de), jako miłość towarzyszącą (cum), a także miłość nakierowaną (in). Warto podkreślić, że z perspektywy trzech przedmiotów tylko w tym ostatnim punkcie mowa jest o Bogu, gdyż tylko w nim miłość odpoczywa we właściwy sposób, jeśli jak zostało powiedziane „pragnienie biegnie a radość odpoczywa”.

30 Tamże (PL 176, 17B-18A). „Potest enim desiderium de proximo currere, sed in proximum non potest. De proximo, ut de ejus, et profectu gaudeat. Cum proximo, ut eum in via Dei et comitem itineris, et socium perventionis habere concupiscat. Sed in proximum non potest, ut in homine spem et fiduciam suam constituat".

${ }_{31}$ Tamże (PL 176, 18A). „Unum est mundi de ipso currere; non cum ipso, aut in ipsum. De mundo desiderium currit, quando inspecto foris Dei opere per admirationem et laudem ardentius intus ad ipsum se convertit. Cum mundo curreret si se pro mutabilitate temporalium, sive dejiciendo in adversis, sive elevando in prosperis huic saeculo se conformaret. In mundum curreret, si in ejus delectationibus semper requiescere vellet". 


\section{MILOŚĆ WYJĄTKOWYM PRZEDMIOTEM CHWALY}

De laude charitatis jest listem Hugona skierowanym do Piotra, przyjaciela i kapłana. Zawiera w sobie prolog, w którym przywołana zostaje retoryczna uwaga o własnej znikomości wobec tematu, i jak to w pochwale, zachętę do czytania i kochania: „wszystko staje się z miłości - miłość posyła i miłość przyjmuje, miłość rozdziela i miłość wyrównuje" ${ }^{32}$. Dalej następuje pochwała miłości jaką potwierdza życie świętych od Abla po św. Pawła. Centralną część tego dziełka stanowi laudacja miłości i określenie jej jako przewodnika po drodze i jako drogi prowadzącej do Boga. Na samym końcu pojawia się określenie samego Boga jako miłości.

Fragmenty odnoszące się do świętych są dość ważne, gdyż podkreślają, że Hugon, a za nim pozostali Wiktoryni, wpisywali swoją pochwałę miłości w tradycję świętych i doktorów Kościoła. Pisze on wprost: „któż spośród świętych żyjących od samego początku świata, nie polecałby miłości zarówno w postaci słów jak i czynów? Miłość ustanowił męczennik Abel, miłość kierowała wyjściem Abrahama z jego ziemi; pierwszy z nich przez miłość niewinnie poniósł śmierć, drugi zaś przez miłość chętnie opuścił swoją rodzinną ziemię; obydwaj z powodu miłości zamienili ziemię dla nieba. Tylko miłość jest tą, która od początku nakłaniała służących Bogu do porzucenia uciech tego świata, do deptania rozkoszy cielesnych, do trzymania w ryzach pożądliwości, podporządkowania pragnień, do gardzenia honorami, a na koniec do odrzucenia wszystkich rozkoszy tego świata a nawet ze względu na pragnienie życia wiecznego, nie obawiać się śmierci" ${ }^{33}$. Zaznaczyć wypada jedynie, że wyraźny tutaj motyw

32 De laude charitatis (PL 176, 971A). „(...) totum ex dilectione fit, dilectio mittit, dilectio suscipit, dilectio est quod tribuitur, dilectio quod recompensatur".

33 Tamże (PL 176, 971A). „Quis enim sanctorum a principio mundi existit, qui non charitatem nobis aut verbo, aut facto commendavit? Charitas Abel martyrem fecit (Gen. IV), charitas Abraham de terra sua eduxit (Gen. XII), quia et ille per charitatem innocenter mortem pertulit, et iste per charitatem natale solum libenter deservit, uterque per charitatem terra coelum commutavit. Charitas sola est quae 
contemptus mundi nie jest tak naprawdę wiodący, a jedynie związany jest z eklezjologicznym myśleniem Hugona na temat miłości skutkującej świętością życia, która następnie ma służyć Kościołowi za przykład. Nie jest to pogarda świata, lecz zachęta do miłości, do miłości porządkującej. Przywołując zdania św. Pawła (Rz 8, 35-39 - „Któż tedy nas odłączy od miłości Chrystusowej”) a także słowa Oblubieńca z Pieśni nad pieśniami (Pnp 8, 6 - „Przyłóż mnie jako pieczęć do serca Twego, jako pieczęć do ramienia twego; bo mocna jest jako śmierć miłość, twarda jako piekło rzewliwość"), Hugon podkreśla trwałość miłości względem jakichkolwiek relacji realizowanych w życiu doczesnym. Warto podkreślić, że przywołany przez Hugona fragment z Listu do Rzymian wyraża nie tylko miłość do Boga, ale jej uszczegółowienie w postaci miłości do Chrystusa.

W dalszych partiach De laude charitatis pojawiają się słowa związane z tytułem artykułu. Najbliższy kontekst w jakim padają można określić jako swoistą wycenę miłości: „O miłości! Cóż mogę o Tobie powiedzieć? W jaki sposób Ciebie wysławić? Gdybym mógł Ciebie doznać mógłbym Ciebie ocenić. Gdybym poznał Twoją wartość, mógłbym zapłacić cenę za Ciebie. Lecz od razu ukazuje się moja znikomość i w swojej mocy nie jestem zdolny do znalezienia Twojej ceny" 34 . Autor, jak się wydaje, nie wyraża w tych słowach retorycznej postawy czy też pozornej pokory. Stawia pytanie: czy człowiek może ocenić wartość miłości - wycenić ją, by następnie na przykład sprzedać albo postawić pod zastaw cokolwiek, co równoważyłoby się z jej ceną. Pytanie to z pewnością zawiera w sobie pytanie dodatkowe: jaka miałaby być miara dla miłości, jakie byłoby kryterium jej oceny. Odpowiedź Hugona na wszystkie te pytania jest oczywiście negatywna, a uzasadniona zostaje dość wyjątkowym

ab initio servis Dei mundi hujus illecebras fugere, voluptates calcare, carnis concupiscentiam cohibere, desideria frangere, honores contemnere, postremo universa praesentis vitae blandimenta resupere, ipsam quoque pro desiderio vitae perpetuae mortem suadet non timere".

34 Tamże (PL 176, 972C). „O charitas quid dicatm de te? Quomodo laudabo te? Si saperem te, appreciarem te; si scirem quanti vales, pretium appenderem pro te. Sed forte excedis augustias meas, nec invenire tuum pretium potero penes me". 
opisem wartościującym miłość: „Ty tylko dla mnie jesteś najdroższa spośród wszystkich rzeczy, ty jesteś radością najużyteczniejszą, tylko Ty jesteś najprzyjemniejsza, tylko Ty sprawiasz największą uciechę, większą radość, obfite nasycenie, zapewniasz bezpieczeństwo, zachowujesz moje szczęście"35.

Słowa te i samo wartościowanie nie przypadkiem mogą budzić skojarzenia ze swoistym „Hugonowym zakładem” (w nawiązaniu do Pascala), bo tak można nazwać to, o czym dalej pisze Hugon, wskazując na konieczność wyboru, jakiego człowiek musi dokonać wybierając miłośćc ${ }^{36}$. Ostatecznie sugeruje on, że i tak zawsze dokonujemy wyboru, nawet jeśli zastanawiamy się nad tym, czy wybrać Boga jako przedmiot miłości: „Powiedz mi o ludzkie serce, co chętniej wybierzesz: zawsze cieszyć się tym światem czy być zawsze z Bogiem. Z pewnością, co bardziej kochasz, to łatwiej wybierzesz. Posłuchaj więc: albo właściwie ustawisz swoją miłość, albo odłożysz wybór. Jeśli ten świat jest piękny, to jak sądzisz, jakie piękno znajduje się w tym, który jest jego stwórcą. Kochaj, by wybierać, kochaj lepiej, by wybrać to, co bardziej pomocne w życiu (ut eligas salubrius). Kochaj Boga, by móc wybrać bycie z Bogiem, wybieraj zatem przez miłość" "37.

35 Tamże (PL 176, 972D). „Tu sola mihi meis omnibus charior, tu sola mihi utilior, tu sola suavior, tu sola jucundior, amplius delectans, abundantius satians, tutius salvans, felicius conservans".

36 „Musisz się zakładać” - pisał Pascal w swoich Myślach - „czy Bóg istnieje, czy też nie". I z pewnością nie chodziło mu o uzasadnienie istnienia Boga (z powodu założonego sceptycyzmu było to niemożliwe), ale o uznanie wartości i sensowności wiary. Hugon pisząc o wartości miłości rozważa ten temat w takim sam sposób jak zrobił to później Pascal. Pascal pisał: „Tak więc trzeba się zakładać; to nie jest rzecz dobrowolna, zmuszony jesteś. Cóż wybierzesz? Zastanów się. Skoro trzeba wybierać, zobaczmy w czym mniej ryzykujesz. Masz dwie rzeczy do stracenia: prawdę i dobro; i dwie do stawienia na kartę: swój rozum i swoją wolę, swoją wiedzę i swoją szczęśliwość; twoja zaś natura ma dwie rzeczy, przed którymi umyka: błąd i niedolę”. Pascal, Myśli (§233), (tłum.) T. Boy-Żeleński, Kraków 2003, s. 64-65.

37 Hugon ze św. Wi k t or a, De laude charitatis (PL 176, 972 D). „Dic mihi, o cor humanum, utrum magis eligis, semper cum Deo? Quod plus diligis, hoc potius eligis. Audi ergo, ut aut corrigas dilectionem, aut non differeas electionem. 
Konieczność wyboru drogi to dla Hugona zwrócenie uwagi na to, co człowiek kocha. Doświadczenie miłości polega na spostrzeżeniu gorliwości, z jaką człowiek pragnie zdobywać przedmiot miłości. Hugon pisze o tym następująco: „To jednak, co bardziej kochasz, bardziej będziesz pożądał by to mieć, będziesz się spieszył by to posiąść. Z powodu miłości bowiem biegniesz i osiągasz to przez miłość. Podobnie to, co bardziej kochasz, to zajmujesz się tym gorliwiej, a przez miłość to osiągasz. Zobacz w jaki sposób miłość jest w Tobie wszystkim: jest twoim wyborem (electio), jest twoim podążaniem (cursus), jest twoim przybyciem (perventio), jest twoim przebywaniem (mansio), jest twoją szczęśliwością (beatitudo). Kochaj Boga, wybieraj Boga, biegnij, osiągaj, posiadaj, raduj się"38.

\section{MILOŚĆ JAKO PRZEWODNIK NA DRODZE}

Hugon zdaje sobie sprawę, że sam wybór miłości (a co za tym idzie i Boga) to nie wszystko. Konieczny jest przewodnik na drodze, który byłby jednocześnie towarzyszem (socios), osobą doświadczoną, pozwalającą na unikanie tego co moglibyśmy nazwać ,własnymi błędami"39. Hugon oczywiście niczego nie napisał o przyjaźni ${ }^{40}$, jednak zmienił odrobinę patrzenie na „miłość bliźnich”, które właściwe było Augustynowi. Biskup Hippony podkreślał wspólnotowy

Si mundus iste pulcher est, qualis putas est pulchritudo ubi Creator mundi est? Dilige ergo ut eligas, dilige melius ut eligas salubrius. Dilige Deum, ut eligas esse cum Deo, ergo per dilectionem eligis".

38 Tamże. (PL 176, 972 D-973A). „Sed quo plus diligis, eo citius pervenire cupis, et festinas ut apprehendas, ergo per dilectionem curris, et per dilectionem apprehendis. Item quo plus diligis, eo avidius amplexaris, ergo per dilectionem frueris. Vide quomodo totum tibi est dilectio, ipsa est electio, ipsa est cursus, ipsa est perventio, ipssa est mansio, ipsa est beatitudo. Dilige ergo Deum, elige Deum, curre, apprehendere, posside, fruere".

39 Tamże (PL 176, 973A). ,Jam inquis, elegi, qua via curram ut perveniam? Per viam Dei curritur ad Deum. Non possum, inquis, viam inexpertam solus currere: da socios ne aberrem".

40 Jak sądzi H. Fleiss, jest to dość charakterystyczny brak w myśli Wiktorynów na temat miłości. Zob. H. F e is s, On love, dz. cyt., s. 61. 
wymiar miłości - wszyscy uczestniczą w miłości Bożej. Wedle niego człowiek kocha bliźnich ze względu na ich dobro, jakim jest Bóg. Hugon z kolei wskazywał, że w trakcie drogi potrzebni są towarzysze, którzy idą w tym samym kierunku, którzy są zdolni do podjęcia trudu zawrócenia nas ze złej drogi. Krótką charakterystykę takich towarzyszy odnaleźć można w jednym zdaniu Hugona: „Prawe są drogi Pana, a sprawiedliwi chodzą nimi. Sprawiedliwość jest więc drogą, a sprawiedliwi są tymi, którzy tą drogą podążają (currunt)" ${ }^{\prime 41}$. W następnych partiach bardzo konsekwentnie wiąże drogę miłości ze sprawiedliwością i ponownie przywołuje temat biegu i odpoczynku: „Posiadasz drogę, posiadasz towarzyszy w drodze, posiadasz dziedzictwo w ojczyźnie niebieskiej - wiesz zatem ku czemu zdążać, z kim i gdzie znajduje się odpoczynek. Tym przez co powinieneś postępować jest sprawiedliwość, tymi z którymi powinieneś postępować są miłujący sprawiedliwość i postępujący za nią. Tym do kogo wyruszasz i w kim odpoczniesz jest twórca sprawiedliwości i źródło życia. Żadna droga nie jest słuszniejsza niż droga sprawiedliwości, żadna wspólnota nie jest lepsza niż ludzi sprawiedliwych, żadna nie jest spokojniejsza niż spoczywająca w Bogu. Ruszaj ostrożnie i pośpiesznie, a wkrótce dotrzesz i szybko odpoczniesz"ł2.

\section{MILOŚĆ JAKO DROGA}

Na podstawie zwrotu pochodzącego od św. Pawła i zapowiadającego Hymn o miłości (, a ja Wam wskaże drogę jeszcze doskonalszą" - 1 Kor 12, 31) Hugon uznaje miłość za samą drogę. Ponownie

${ }^{41}$ Hug on ze św. W i k t or a, De laude charitatis (PL 176, 973B). „Recte sunt viae Domini, et justi ambulabunt in eis. Justitia est ergo via, et justi sunt qui in via currunt".

42 Tamże (PL 176, 973B-C). „Habes ergo viam, habes socios in via, habes haereditatem in patria, habes qua pergas, cum quibus pergas, ubi requiescas. Qua pergas, justitiam. Cum quibus pergas, amantes et sectantes justitiam. Quo pervenias, et in quo requiescas, et auctorem justitiae, et fontem vitae. Nulla via justitia rectior, nulla societas justorum societate melior, nulla requies Deo tranquilior. Perge securus, perge festinus, ut velociter pervenias, feliciter requiescas". 
w formie pytania wybrzmiewa jego wypowiedź na ten temat: „Cóż więcej mógłbym powiedzieć o Tobie, miłości? Już powiedziałem, że jesteś przewodniczką na drodze do Boga, a co by było, gdybym nazwał Cię samą drogą do Boga? Z całą pewnością o miłości, jesteś

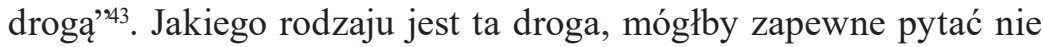
tylko XII-wieczny kanonik regularny, ale także każdy kto kocha: jaka jest to droga? Przytoczę większy passus, żeby podkreślić faktyczną laudację na temat miłości: , Jesteś drogą najdoskonalszą, najznamienitszą, drogą, która czyni kręte ścieżki prostymi, która proste drogi czyni znanymi. Ty jesteś głową wszystkich prawych dróg - biorą one z ciebie początek i do ciebie powracają. Boże przykazania, które są Jego drogami, są również twoimi, gdyż od ciebie zależą i w tobie się zawierają. Ty jesteś pełnią sprawiedliwości, doskonałością prawa, spełnieniem cnót, poznaniem prawdy. Jaką jesteś drogą o miłości? Najdoskonalszą, przysposabiającą, prowadzącą, doprowadzającą. Czyją jesteś drogą? Drogą człowieka do Boga i drogą Boga do ludzi’"44.

Uwagi Hugona o aksjologicznym charakterze w jego De laude charitatis przechodzą $\mathrm{w}$ pewnym momencie wprost $\mathrm{w}$ rozważania teologiczne, uwzględniające historię zbawienia. Aby je zrozumieć, należy odnieść się do głównego teologicznego traktatu Hugona, a mianowicie De sacramentis christianae fidei. Rozważając naturę człowieka Hugon wskazuje na trojaki stan: 1) przed grzechem - stan utworzenia; 2) po grzechu - stan nie będący pełną ruiną, ale ze stałą skłonnością do grzechu; 3) po zmartwychwstaniu Chrystusa ze śmierci - uwolnienie od grzechu i winy ${ }^{45}$. Hugon potrójnie mówi

43 Tamże (PL 176, 974A). „Quid amplius dicam de te, charitas? Ducem te dixi in via Dei. Et quid si teipsam viam Dei dixerim? Utique sic charitas tu via es".

44 Tamże (PL 176, 974 A-B). ,Tu es namque via superexcellens, via supereminens, vias distortas dirigens, vias rectes ostendens. Tu es caput viarum rectarum, omnes viae rectae a te exeunt et in te recurrunt. Nam praecepia Dei viae sunt ejus, quae omnia a te pendent et in te consistunt. Tu es plenitudo justitiae, perfectio legis, consummatio virtutis, agnitio veritatis. Via igitur es, o charitas. Qualis via? Superexcellens, suscipiens, dirigens et producens. Cuius via? Via hominis ad Deum, et via Dei ad homines".

45 Por. K. M a r c i n i a k, Hugo ześw. Wiktora (ok. 110-1141), w: Drogi Zbawienia. Od Biblii do Soboru, „Studia Instituti Thomistici”, t. 4, Poznań-Warszawa-Lublin 
o tych trzech stanach, biorąc pod uwagę oddzielenie, chwałę i miłość. I tak w pierwszym stanie funkcjonowało oddzielenie wyłącznie Boga i człowieka. W stanie skłonności do grzechu, między Bogiem i człowiekiem oddzielenie związane jest z szatanem, który odciąga człowieka od stwórcy. W trzecim stanie następuje uznanie i przyjęcie wszystkiego przez Boga. Biorąc pod uwagę chwałę Boga, należałoby powiedzieć, że w pierwszym stanie liczyła się wyłącznie chwała Boga i nic nie powstawało przeciwko niej. W drugim stanie nic nie dokonuje się dla chwały Boga, ale wszystko zaczyna być formułowane przeciw niej. Trzeci stan ma być ponownym przywróceniem całkowitej chwały dla Boga. W ostatnim punkcie, w schemat trzech stanów przedstawiających historię zbawienia, wpisana zostaje miłość. Pierwszy etap stanowiła miłość dla chwały Boga, w drugim pojawiła się konieczność i nieprawość (przeciw miłości Boga), a wreszcie ostatni, eschatologiczny wymiar będzie wyrażał tylko miłość (sola (charitas) $)^{46}$.

Miłość dla Hugona jest czynnikiem łączącym Boga z człowiekiem - co nie dokonuje się tylko ze strony człowieka, ale również ze strony Boga. To miłość jako droga, „wymusiła” na Bogu zbawienie: „Błogosławiona droga, która jako jedyna zna cenę naszego zbawienia. Ty prowadzisz Boga do człowieka, Ty człowieka przeprowadzasz do Boga. Bóg zniża się (zstępuje), gdy przychodzi do nas, my wspinamy się, gdy kierujemy się (wstępujemy) do Niego. Ani Bóg, ani my bez Ciebie, nie moglibyśmy przechodzić do siebie. Jesteś pośrednikiem godzącym przeciwników, łączącym rozdzielonych, wyrównującym w pewien sposób nierównych"47.

1970, s. 392-398.

46 Hugon ze św. Wi k to r a, De sacramentis christianae fidei. I, 6, 10 (PL 176, 269D-270B).

47 Hu g on z e św. Wi k t or a, De laude charitatis (PL 176, 974B). „O beata via, quae sola commercium nostrae salutis agnoscis! Tu Deum ad hominem deducis, tu hominem ad Deum dirigis. Ille descendit quando ad nos venit; nos ascendimus, quando ad illum imus. Nec ille tamen nec nos nisi per te ad alteruirum transire possumus. Tu mediatrix es, adversos concilians, disjunctos socians etiantum dispares, quodammodo coaequans". 
Niezwykle interesujące są uwagi Hugona na temat tego, że Bóg podlega sile miłości. W jego ujęciu można wręcz mówić o tym, że miłość „poniża” samego Boga: „Boga poniżasz, nas wywyższasz, Jego pociągasz na dno, nas wnosisz na wyżyny. W ten sposób to czynisz, że zstąpienie Boga nie jest poniżające lecz miłosierne, a nasze wywyższenie nie wbija nas w dumę, lecz daje zaszczyty"48. A jak pisze nieco dalej, miłość nie tylko poniża Boga, ale wręcz go wiąże i ogranicza: „Wielką moc posiadasz, o miłości, że tylko Ty możesz ściągnąć Boga z nieba na ziemię. Jak mocne są Twoje więzy, że zarówno Boga potrafisz spętać a człowieka krępując potrafisz powstrzymać od nieprawości'49.

\section{PLYNNA RZECZYWISTOŚĆ A MILOŚĆ}

W swoim krótkim kazaniu Quod amor Dei sit vita cordis, Hugon wskazuje, że rzeczywistość otaczającą człowieka można określić jako płynną, zanurzoną (diluvium) ${ }^{50}$. Wprost nawiązując do biblijnego potopu pokazuje, że możliwe jest ponowne zalanie świata przez wodę. Budowanie wiary i miłości jest budowaniem jedynego środka umożliwiającego przetrwanie: „Abyś to dobrze zrozumiał, niech mi będzie wolno podać pewien przykład. Cały ten świat (universus iste mundus) jest jakby zanurzony, ponieważ - przez falowanie związane z niepewnymi skutkami - wszystko, co jest na tym świecie, to wydarzenia

48 Tamże (PL 176, 974A). ,Deum humilians, nos sublimans, illum ad ima trahens, nos ad summa erigens. Sic tamen ut nec abjecta, sed pia ait ejus descensio, nec superba, sed gloriosa sit nostri exaltatio".

49 Tamże (PL 176, 974A). „(...) magnam ergo vim habes, charitas, tu sola Deum trahere potuisti de caelo ad terras. O quam forte est vinculum tuum, quo et Deus ligari potuit, et homo ligatus vincula iniquitatis disrupit!”. W kontekście uwag o pięknie W. Bajor podkreśla, pewną paradoksalność wypowiedzi Hugona. Brzydota w jego estetyce spełnia niezwykle ważna funkcję - zmusza do pragnienia Piękna doskonałego. W ten sposób chrześcijańska myśl Hugona zyskała ontologiczne uzasadnienia w postaci neoplatońskiego ujęcia relacji między Bogiem i światem. Zob. W. B a j o r, «Zbawcze piękno» w teorii estetycznej Wiktorynów, dz. cyt., s. 71.

50 Hugon ze św. Wiktora, Quod amor Dei sit vita cordis (PL176, 564 B). 
zmieniające się na podobieństwo płynącej wody. Prawdziwa wiara zaś, która nie obiecuje rzeczy ulotnych, lecz wieczne, unosi umysł od pożądania tego świata do pożądania rzeczy boskich, ratuje go jakby przed sztormem. Bądź pewien, że woda potrafi to spowodować, jednak nie może całkowicie zatopić umysłu, gdyż nawet jeśli z konieczności posługuje się on tym światem, to nie jest całkowicie uwikłany w jego pożądanie" 51 .

Wiara dla Hugona jest gwarantem stabilności. Kto nie wierzy, ten jest człowiekiem bez okrętu, pozostawionym na morzu i przyjmującym na siebie cały impet płynącej wody. Wiara w rzeczy wieczne, powiązana z miłością tego, co przejściowe, nie gwarantuje przemierzania fal burzliwego morza. Jego zdaniem jedyną gwarancję daje wiara i miłość Boga, które oznaczają nie opuszczanie okrętu, a także naśladowanie stabilności ziemi w trakcie burzy. Hugon podsumowuje swój kazanie następująco: „Jeśli zatem chcemy w sposób nienaruszony przeprawić się przez to wielkie morze, na początku musimy zbudować okręt, abyśmy mieli pełnię wiary. Następnie okręt wiary (navem fidei) powinniśmy otoczyć miłością, abyśmy zarówno wierzyli w to, co mamy kochać i byśmy kochali to, w co wierzymy. Tak więc prawo Boże będzie w naszym sercu przez słuszne poznanie wiary, a serce nasze będzie w prawie Bożym przez miłość"

51 Tamże (PL176, 564 B-C). „Ut autem promotionis hujus aliquod tibi exemplum subjiciam, universus iste mundus quasi quoddam diluvium est; quia omnia quae in hoc mundo sunt ad similitudinem aquae incertis eventibus fluctando decurrunt. Vera autem fides, quae non transitoria, sed aeterna promittit, quasi a quibusdam fluctibus sic a mundi hujus cupiditate in superna animum attolit, et portari quidem $\mathrm{ab}$ aquis potest, sed mergi omnino non potest, quia ad necessitatem hoc mundo utitur, sed ejus desideriis per affectum non implicatur".

52 Tamże (PL 176, C-D). „Primum ergo si hoc mare magnum illaesi pertransire volumus, fabricemus navem, ut fidem integram habeamus. Deinde navem fidei inhabitemus per charitatem, ut et credamus quod dilligere debemus, et diligamus quod credimus. Sicque et lex Dei in corde nostro sit per rectae fidei cognitionem, et cor nostrum in lege Dei sit per dilectionem". 


\section{ZAKOŃCZENIE}

Hugon ze św. Wiktora w swojej koncepcji miłości wyraża troskę o uleczenie fatalnego stanu człowieka po grzechu pierworodnym. Miłość jest czynnikiem zrównującym rzeczywistość Boską i ludzką, gdyż tylko w ten sposób może zostać zrealizowane zbawienie człowieka i uzyskanie przez niego pełni szczęścia. W życiu chrześcijanina sama wiara nie wystarcza, lecz musi zostać przepojona miłością. Jedynie poprzez czyny miłości można mówić o realizacji wiary chrześcijańskiej. Hugon swoje ujęcie miłości wyraża poprzez jej stałe wartościowanie, które poprowadzone jest aż do jej zabsolutyzowania. Miłość jest drogą, przewodnikiem na drodze, ale pozostaje także kresem drogi. Poszukiwanie stabilności (stałości) przedmiotu miłości jest, wedle Hugona, związane z ryzykiem porzucenia przedmiotu miłości, który mógłby okazać się niewystarczający. Hugon, choć nie napisał odrębnego, syntetycznego działa poświęconego miłości, to jednak jego opuscula na ten temat wystarczająco dobrze ukazują go jako autora, który pokazuje dynamikę miłości wypływającej z wnętrza człowieka (źródło dynamizmu umieszczone zostało w człowieku przez Stwórcę) i zbliżającej człowieka do Boga. Jeśli celem człowieka, a także celem miłości jest Bóg, to człowiek posiadający ją może w pełni korzystać i doskonalej rozumieć wiedzę zdobywaną w trakcie uczenia się. Jednak trzeba podkreślić to, że wiedza zdobywana przez ,właściwie” kochający umysł prowadzi do lepszego poznania tego, który jest jego Stwórcą. Tylko w kontekście wypowiedzi Hugona na temat relacji między miłością a poznaniem, można zrozumieć to, co wypowiedział Ryszard, jego uczeń i następca w szkole Wiktorynów: ,powinno w nas zawsze wzrastać miłość płynąca z poznania i niemniej poznanie płynące z miłości”’33.

53 Ryszard ze św. W iktor a, Beniamin major IV, 10 (PL 196, 145C). „Debet itaque in nobis crescere semper et ex cognitione dilectio, et nihilominus ex dilectione cognitio (...)". Zob. M. G o g a c z, Filozofia bytu w „Beniamin Major” Ryszarda ze św. Wiktora, Lublin 1957, s. 1 (motto do książki). 


\section{„Oh Love! What can I tell about you?". The praise of the love in the works of Hugh of St. Victor Summary}

Hugh of St. Victor was one of the most important theologians, exegetes, educators and mystics in the twelfth century. One of the topics which he undertook was the value of love. In his very short, but very influential works, he expressed an extraordinary praise of love. Love is defined by him as both a road, as the one who accompanies the road, and also as the purpose of the road. Love is an agent which equates divine and human reality, because only in this way man can be saved and his happiness fully realized. Recognition the law of God and justice is effect of the faith, but their realization is the works of love. Although the approach of love has its source in St. Augustine, however, the main focus of it is the categories of running and rest (cursus et requies), and not the category of inclination or impetus (pondus).

Słowa kluczowe: Hugon ze św. Wiktora, wiktoryni, miłość Boga, miłość bliskich, pochwała miłości

Keywords: Hugh of Saint Victor, Victorine, love of God, brotherly love, praise of love

Nota 0 autorze: Michał Zembrzuski - dr filozofii, adiunkt w Katedrze Historii Filozofii Starożytnej i Średniowiecznej na Wydziale Filozofii Chrześcijańskiej Uniwersytetu Kardynała Stefana Wyszyńskiego w Warszawie.

\section{Bibliografia:}

Andrzejuk A., Metafizyka obecności. Wstęp do teorii relacji osobowych, Wydawnictwo Uniwersytetu Kardynała Stefana Wyszyńskiego, Warszawa 2012.

Augustyn, O nauce chrześcijańskiej, (tłum.) J. Sulowski, „Pisma Starochrześcijańskich Pisarzy", t. 22, Wydawnictwo ATK, Warszawa 1979, s. 17-134.

Augustyn, O Trójcy świętej, (tłum.) M. Stokowska, „Księgarnia św. Wojciecha”, Poznań-Warszawa-Lublin 1962.

Augustyn, Państwo Boże, (tłum.) T. Kubicki, Wydawnictwo „Marek Derewiecki”, Kęty 2015.

Augustyn, Wyznania, (tłum.) Z. Kubiak, „Znak”, Kraków 2008.

Bajor W., «Zbawcze piękno» w teorii estetycznej Wiktorynów, „Roczniki Kulturoznawcze" 3 (2012), s. 67-81.

Coolmann B. T., The Theology of Hugh of St. Victor. An Interpretation, Cambridge University Press, New York 2010. 
Czubak M., Jednostka i wspólnota w ujęciu Aelreda z Rievaulx, Wydawnictwo Naukowe „Semper”, Warszawa 2010.

Feiss H., On love. A selection of works of Hugh, Adam, Achard, Richard, Godfrey of St. Victor. Victorine Texts in Translation, t. 2, Brepols, Turnhout 2012.

Gogacz M., Filozofia bytu w „Beniamin Major” Ryszarda ze św. Wiktora, Lublin 1957.

Hugon ze św. Wiktora, Opera omnia, in: J.-P. Migne, Patrologia Latina Cursus Completus, t. 175, Parisiis 1854 (Commentaria in Hierarchiam coelestem S. Dionysii Areopagitae 923A-1154C).

Hugon ze św. Wiktora, Opera omnia, in: J.-P. Migne, Patrologia Latina Cursus Completus, t. 176, Parisiis 1880 (De sacramentis fidei Christianae183A-618B; De laude charitatis 969D-976D; Quod amor Dei sit vita cordis 563D-565A; De substantia dilectionis et charitate ordinata 15A-18B).

Janeczek S., Hugon ze św. Wiktora. Myśl filozoficzna, „Powszechna Encyklopedia Filozofii", t. 4, Lublin 2003, s. 620-622.

Marciniak K., Hugo ze św. Wiktora (ok. 110-1141), w: Drogi Zbawienia. Od Biblii do Soboru, „Studia Instituti Thomistici”, t. 4, Poznań-Warszawa-Lublin 1970, s. 392-398.

Pascal, Myśli, (tłum.) T. Boy-Żeleński, „Zielona Sowa”, Kraków 2003.

Rorem P., Hugh of Saint Victor, Oxford University Press, New York 2009.

Squire A., Introduction, w: Hugh of Saint Victor. A Selected Spiritual Writings, Harper \& Row, New York-Evanston 1962, s. 13-42.

Tichy R., Hugon ze św. Wiktora, w: M. Frankowska-Terlecka (red.), Wszystko to ze zdziwienia. Antologia tekstów filozoficznych z XII wieku, Wydawnictwo Naukowe PWN, Warszawa 2006, s. 269-278.

Tichy R., Mistyczna historia człowieka wedtug Bernarda z Clairvaux, „Flos Carmeli”, Kraków 2011. 